\title{
PKM Education on Occupational Safety and Health in the COVID-19 Pandemic to Employees of PT. Astamukti Airtech Nusatama
}

\author{
Galuh Krisna Dewanti, Elfitria Wiratmani, Ridwan Usmana) \\ Program Studi Teknik Industri, Universitas Indraprasta PGRI Jakarta \\ a)Corresponding Author: ridwansmn@gmail.com
}

\begin{abstract}
The Covid-19 pandemic has changed the order of society, it is recommended that they are even forced to stay at home, go to school, work and even worship at home. Almost all countries urge their citizens not to move outside the home if there is no urgent need. Informal workers because around 61 percent of the global workforce are particularly vulnerable during the pandemic, have to face higher OSH risks, and lack adequate protection. Occupational Health and Safety (K3) is a thought and effort to ensure the integrity and perfection of both the physical and spiritual workforce, in particular, the implementation of Community Service (PKM) in the Covid-19 pandemic to employees of PT. Astamukti Airtech Nusatama. The results of the socialization and education of $\mathrm{K} 3$ employees better understand and realize the importance of the OHS system and the implementation of the Covid-19 pandemic health protocol in the workplace, the importance of management support that continuously provides understanding through discussion and training so that they are aware, understand and be able to consistently apply $\mathrm{K} 3$ and health protocols continuously in the corporate environment.
\end{abstract}

Keywords: PKM, Covid-19 Pandemic Education

\section{INTRODUCTION}

Over the past two decades, the world has witnessed several infectious disease outbreaks that have caused and shown to spread very rapidly. The Covid-19 pandemic has changed the order of society, it is recommended that they are even forced to stay at home, go to school, work, and even worship. Almost all countries urge their citizens not to move outside the home if there is no urgent need.

The ILO (International Labor Organization) Centenary Declaration adopted in June 2019 declares "safe and healthy working conditions as the basis of decent work". This is even more important today, given the importance of ensuring workplace safety and health in pandemic management and the ability to return to work. Coronavirus disease (COVID-19) is an infectious disease caused by the newly discovered coronavirus known as severe acute respiratory syndrome coronavirus 2 (SARS-CoV-2). The first human case of COVID-19 was identified in Wuhan City, China in December 2019.(Mia \& Putul, 2020) When a person with COVID-19 coughs or exhales, they release a splash of infected fluid. Measures to respond to this pandemic also have a direct impact on markets, supply (production of goods and services), demand (consumers and investment), and the world of work. Quarantine and disruption to the business world, travel bans, school closures, and other closure measures, have a sudden and drastic impact on workers and companies. (Convention \& Group, 1944).

Informal workers who account for about 61 percent of the global workforce are particularly vulnerable during the pandemic as they have to face higher OSH risks and a lack of adequate protection. The workplace is an effective means where employers and workers, together, can disseminate information and conduct socialization related to occupational safety and health (K3), including preventive and protective measures to reduce the spread of infectious diseases. (Covid- \& Work nd) Occupational safety and health (K3) is a thought and effort to ensure the integrity and perfection of both the 
physical and the spiritual workforce in particular, and humans in general, the results of work and culture towards a just and prosperous society, as well as creating protection and security from the risk of accidents and physical, mental and emotional hazards to workers, companies, communities and the environment. (Sukanta et al., 2020) By having a comprehensive emergency preparedness plan in the workplace designed to address health crises and epidemics, the workplace may be better equipped to develop a rapid, coordinated, and effective response, while adapting such measures to emergencies that are (Mia \& Putul, 2020) Continuous monitoring of OHS conditions and appropriate risk assessment will be required to ensure that control measures are specifically adapted to the changing process, working conditions and characteristics of the workforce during critical times, a number of its provisions and recommendations offer preventive and protective measures to reduce the negative health and safety impacts of pandemics such as COVID-19 in the world of work. (Ri \& Tirtonegoro, 2020).

\section{METHOD}

Implementation of Community Service (PKM) activities for Occupational Safety and Health (K3) education to employees at PT. Astamukti Airtech Nusatama because of the current Covid19 pandemic, PKM is carried out online using the zoom application. This activity is carried out in three stages, namely: The first stage of the survey, preparation of socialization, and implementation of online PKM, the implementation is 1 . Online survey to partners and discussions with leaders regarding appropriate material during the pandemic for employees. 2. The process of preparing PKM (K3) materials. 3. Implementation of PKM using PowerPoint presentation methods, discussions, and questions and answer (Usman, R., Putra, M. F., Ikha, R., Sari, 2019) Currently, employees are required to know the dangers, risks that will be caused and the implementation of preventive measures aimed at protecting employees, from this education employees are expected to be ready related to preventive measures, risk control, OHS which includes emergency preparedness procedures, planning responses for various scenarios, including moderate outbreaks or severe pandemics. (Di \& Tein, 2020).

\section{RESULTS}

The implementation of activities carried out by the PKM team from Indraprasta University PGRI Jakarta. Based on the results of the socialization of PKM activities, Occupational Safety and Health (K3) education in the Covid-19 pandemic can provide additional insight to PT. Astamukti Airtech Nusatama obtained the following results: a. Realization of activities, starting with a pre-test before the material counseling begins to participants to determine the initial competencies related to participants' understanding, b. Explanation of the material through visualization demonstrations as well as discussions, case studies, and presentations. After the delivery of the material is complete, then proceed with a question and answer session to the speakers, c. In the closing stage, the team gave a post-test to participants, aiming to find out the final competency level of mastery of the material after receiving education, the results of increasing knowledge are shown in the image below: 


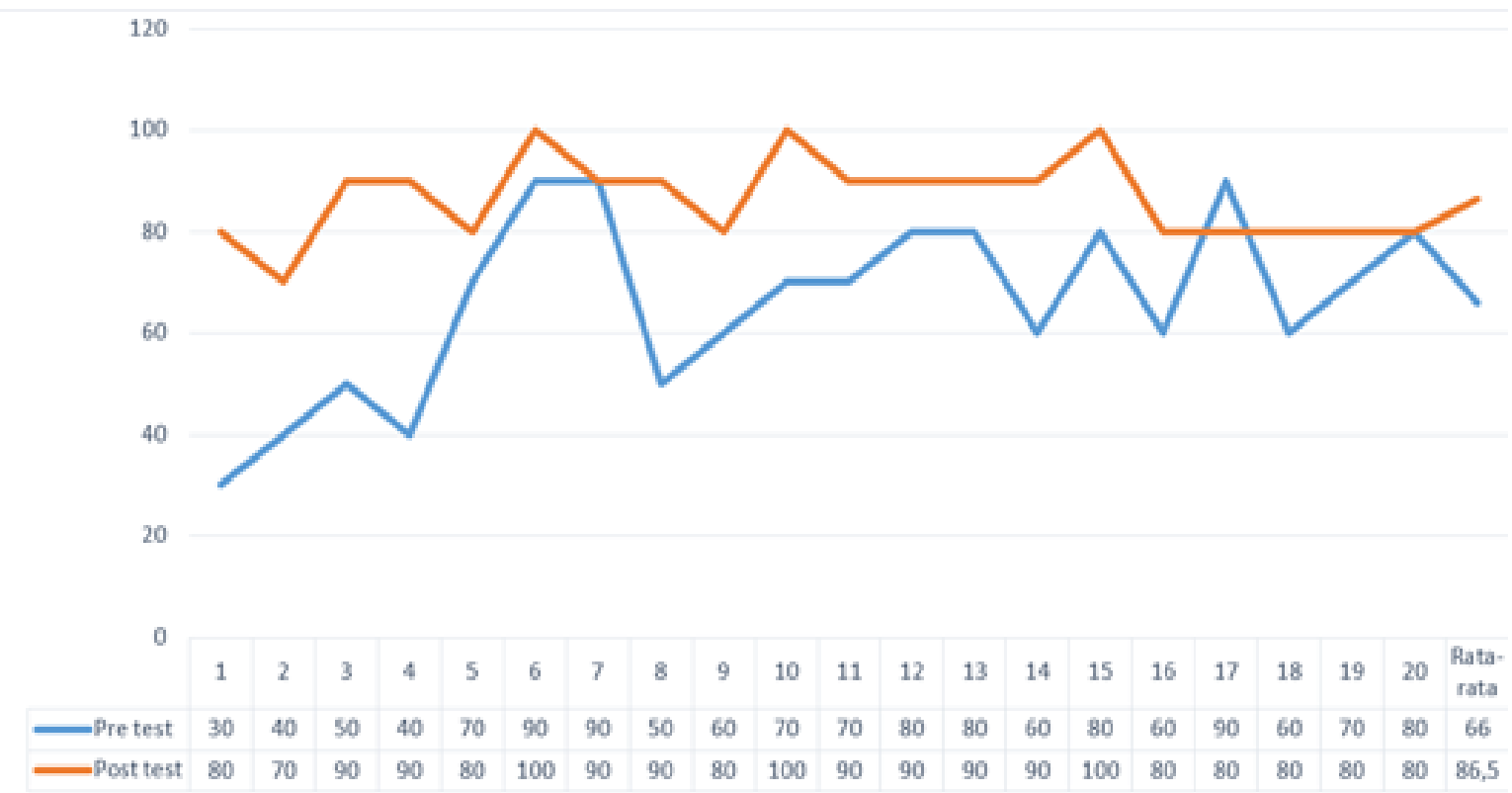

Figure 1. Results of PKM education for pre-test and post-test employees

Based on the data in Figure 1 above, there is a change, namely before the pre-test education the score was 66 and after the education was carried out the score became 86.5. This data shows the addition of participants' knowledge/knowledge regarding Occupational Safety and Health (K3) education in the Covid-19 pandemic. (Setiawan et al., 2018).

\section{DISCUSSION}

Community service implementation activities involving the management and employees of PT. Astamukti Airtech Nusatama. The results of the activity can be seen from additional knowledge and vigilance in working during the Covid-19 pandemic so that the overall process of abdimas activities can be carried out properly. Employees are expected to be ready regarding risk prevention and control measures, K3 which includes clear procedures on emergency preparedness, planning responses for various scenarios, including the Covid-19 pandemic outbreak (Di \& Tein, 2020).

\section{CONCLUSIONS AND RECOMMENDATIONS}

The results of community service activities through training and education on Occupational Safety and Health (K3) in the Covid-19 pandemic can be concluded as follows (1) Management and training participants, namely employees of PT. Astamukti Airtech Nusatama better understands and is aware of the importance of implementing the OHS system and using personal protective equipment (PPE) in the Covid-19 pandemic in the work environment. (2) Management and participants can identify potential hazards, assess and control risks in the work environment. (3) Socialization participants are expected to understand the importance of complying with and implementing health protocols by preparing facilities such as health clothes, masks, hand washing, and soap areas, keeping a distance, and spraying disinfectants regularly in the work environment. (4) the awareness of participants to use masks, the habit of washing hands with soap with running and clean water, and keeping a distance for any activities. The suggestions that can be given are (1) It takes a continuous commitment from management to provide policies related to K3 facilities and Covid-19 prevention and handling facilities to prevent the spread. (2) Awareness and responsibility by leaders and participants are always reminded to comply with and obey K3 regulations and health protocols. (3) There is a need for regular followup evaluations related to programs that have been implemented as a benchmark for the success of implementing K3 during the pandemic. (Di \& Tein, 2020). 


\section{ACKNOWLEDGMENTS}

Our gratitude goes to the leadership and employees of PT. Astamukti Airtech Nusatama has given permission and time to carry out PKM. To the Chancellor of Universitas Indraprasta PGRI who has supported this PKM so that it runs smoothly, then to the head of the community service center who has helped with our correspondence process, and made the PKM program a success so that it is more memorable and useful for all.

\section{REFERENCES}

Convention, M. L., \& Group, W. (1944). Programme of Meetings. The British Journal of Radiology, 17(193), 2-2. https://doi.org/10.1259/0007-1285-17-193-2-b

Covid-, P., \& Kerja, T. (n.d.). Kumpulan Panduan Pencegahan Penularan.

Di, I., \& Tein, P. T. (2020). PELATIHAN SISTEM MANAJEMEN K3 DAN NEW NORMAL. 2-7.

Mia, M. T., \& Putul, S. J. (2020). Pages 21-32 To Cite This Article: Md. Tuhin Mia and Sharmin Jahan Putul. Covid-19 in Malaysia: Protection of Migrant Workers in this Pandemic Situation. Journal of Asian and African Social Science and Humanities, 6(3), 21-32.

Ri, K. K., \& Tirtonegoro, R. S. (2020). SAFETY DAN PENCEGAHAN COVID - 19 DI TEMPAT KERJA ERA NEW NORMAL.

Setiawan, H., Roslianti, E., Firmansyah, A., \& Fitriani, A. (2018). Promosi Kesehatan Pencegahan Hipertensi Sejak Dini. 41-45.

Mia, M. T., \& Putul, S. J. (2020). Pages 21-32 To Cite This Article: Md. Tuhin Mia and Sharmin Jahan Putul. Covid-19 in Malaysia: Protection of Migrant Workers in this Pandemic Situation. Journal of Asian and African Social Science and Humanities, 6(3), 21-32.

Sukanta, Sari, D. A., \& Musadad, A. (2020). Pelatihan Sistem Manajemen K3 dan New Normal Industri Di PT TEiN Karawang. Prosiding Seminar Nasional Rekarta 2020, 105-113. https://journal-litbang-rekarta.co.id/index.php/semarta/article/view/296

Usman, R., Putra, M. F., Ikha, R., Sari, P. (2019). PENGOLAHAN LIMBAH AMPAS EKSTRASI JAMU MENJADI PUPUK KOMPOS. Prosiding Seminar Nasional Pengabdian Masyarakat LPPM UMJ, E-ISSN: 27, 1-7. 


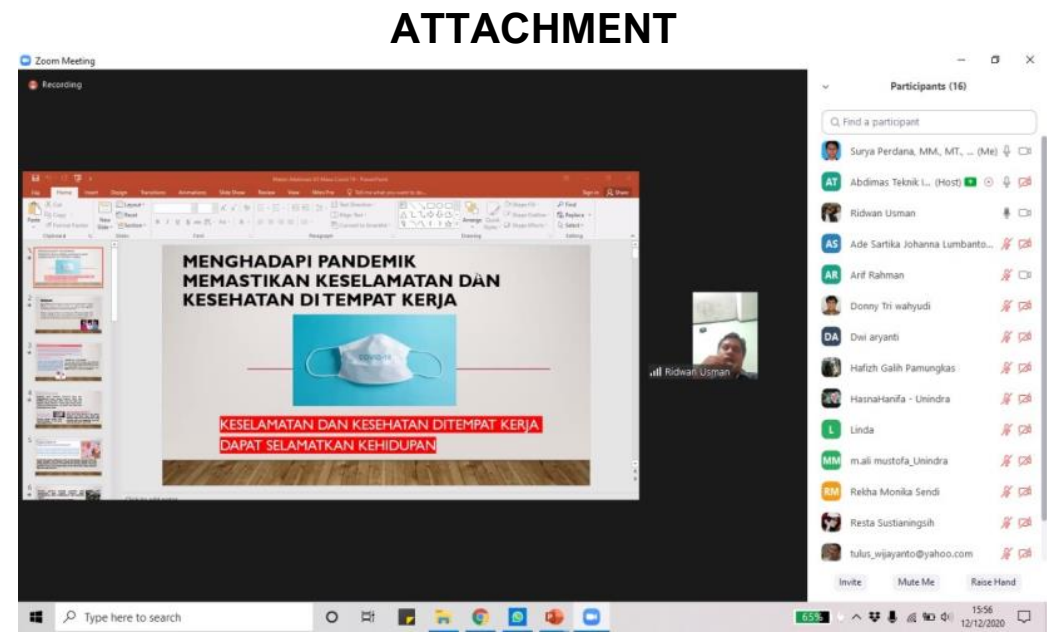

Figure 1. Presentation of the material

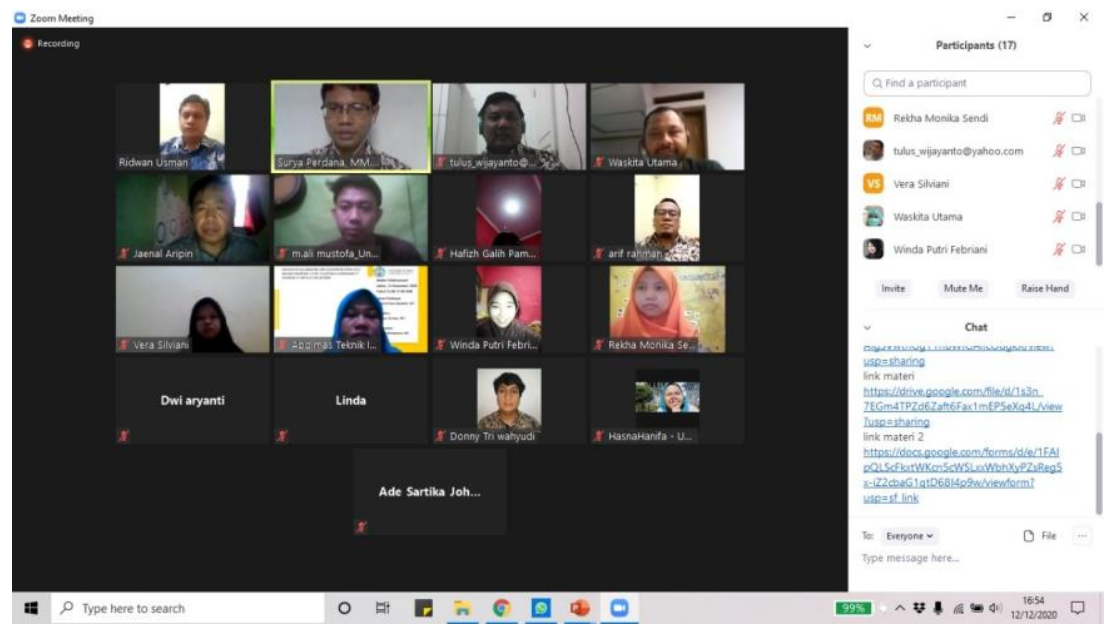

Figure 2. Discussion and Questions and Answers to Participants 